\section{ON THE WYANDOTTE CAVE AND ITS FAUNA *}

THE Wyandotte Cave traverses the St. Louis 1 Limestone of the Carboniferous formation in Crawford County, in South-Western Indiana. I do not know whether its length has ever been accurately determined, but the proprietors say that they have explored its galleries for twenty-two miles, and it is probable that its extent is equal to that of the Mammoth Cave in Kentucky. Numerous galleries which diverge from its known courses in all directions have been left unexplored.

The Wyandotte Cave is as well worthy of popular favour as the Mammoth. It lacks the large bodies of water which diversify the scene in the latter, but is fully equal to it in the beauty of its stalactites and other ornaments of calcyte and gypsum. The stalactites and sta-

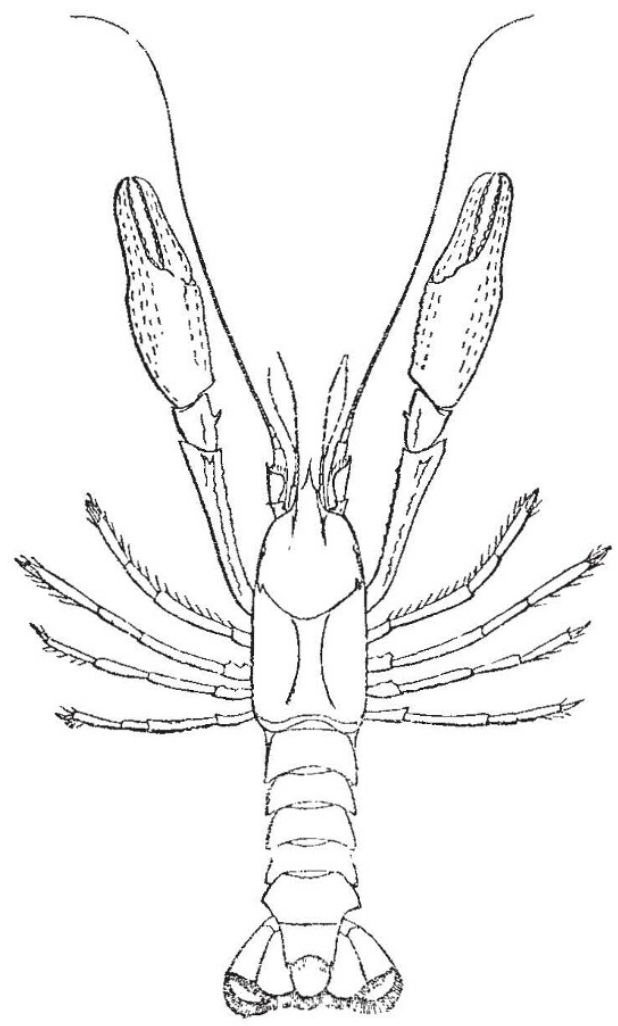

FIG. 1.-Orconectes inermis Cope, natural sizc.

lagmites are more numerous than in the Mammoth, and the former frequently have a worn, or maccaroni-like form, which is very peculiar. They twist and wind in masses like the locks of Medusa, and often extend in slender runners to a remarkable length. The gypsum rosettes occur in the remote regions of the cave, and are very beautiful. There are also masses of amorphous gypsum of much purity. The floor in many places is covered with curved branches, and, what is more beautiful, of perfectly transparent acicular crystals, sometimes mingled with imperfect twin-crystals. The loose crystals in one place are in such quantity as to give the name of "Snow Banks" to it. In other places it takes the form of japanning on the roof and wall rock.

In one respect the cave is superior to the Mammothin its vast rooms, with step-like domes, and often huge stalagmites on central hills. In these localities the rock

- Reprinted from the American Naturalist, to the kindness of the oditor of which journal we are also indebted for the loan of the cuts. has been originally more fractured or fragile than elsewhere, and has given way at times of disturbance, piling masses on the floor. The destruction having reached the thin-bedded strata above, the breaking down has proceeded with greater rapidity, each bed breaking away over a narrower area than that below it. When the heavily-bedded rock has been again reached, the breakage has ceased, and the stratum remains as a heavy coping stone to the hollow dome. Of course the process piles a hill beneath, and the access of water being rendered more

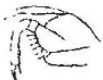

FIG. 2 .

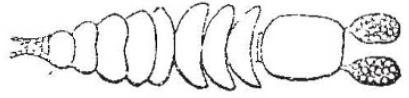

Fig. 3
Cacidotea microcephala Cope.-Fig. 2: The mandible and palpi of right side more enlarged. The outer palpus lies above the lateral plate, and its origin was not seen. Fig. 3 : The same; magnified 6.5 times.

easy by the approach to the surface, great stalactites and stalagmites are the result. In one place this product forms a mass extending from floor to ceiling, a distance of thirty or forty feet, with a diameter of twenty-five feet,

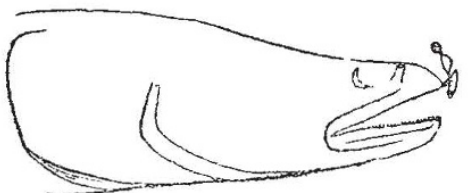

Fig. 4.-Cauloxerus stygzws in position on the lip of Amblyopsis spelaus, enlarged.

and a beautifully fluted circumference. The walls of the room are encrusted with cataract-like masses, and stalagmites are numerous. The largest room is stated to be 245 feet high, and 350 feet long, and to contain a hill of

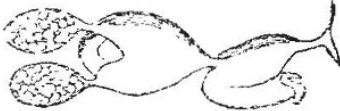

Fig. 5 .

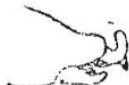

Fig. 6.

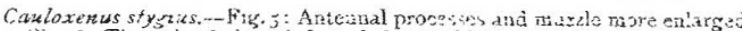
fig. 6 : The animal viewed from below, with an infero-lateral view of the cephaluthorax.

175 feet in height. On the summit are three large stalagmites, one of them pure white. When this scene is lit uo it is peculiarly grand to the eye of an observer at the foot of the long hill, while it is not less beautiful to those on

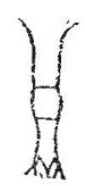

FIG. 7

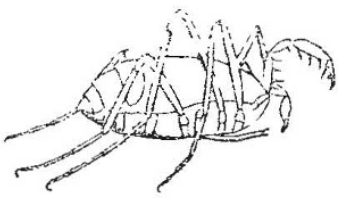

FIG. 8.
Erebomaster favescens.-Fig. 7: Male organ from below. Fir. 8: The same; magnified 7.6 times.

the summit. There is no room in the Mammoth Cave equal to these two.

An examination into the life of the cave shows it to have much resemblance to that of the Mammoth. The following is a list of sixteen species of animals which I obtained, and by its side is placed a corresponding list of the species obtained by Mr. Cooke and others, at the Mammoth Cave. These number seventeen species. As the Mammoth has been more frequently explored, while two days only were devoted to the Wyandotte, the large 
number of species obtained in the latter suggests that it is the richer in life. This 1 suspect will prove to be the case, as it is situated in a fertile region. Some of the animals were also procured from caves immediately adjoining, which are no doubt connected with the principal one.

Of the out-door fauna which find shelter in the cave, bats are, of course, most numerous. They are probably followed into their retreat by the eagle and other large owls. The floors of some of the chambers were covered to a considerable depth by the castings of these birds, which consisted of 'bats' fur and bones. It would be worth while to determine whether any of the owls winter there.

LIST OF LIVING SPECIES IN THE TWO CAVES.

$$
\text { WYANDOTIE. }
$$

$$
\text { MAMмоTн. }
$$

Amblyopsis spelæus DeKay.

Erebomaster flavescens Cope.$$
\text { Amblyopsis spelæus DeKay. }
$$$$
\begin{aligned}
& \text { Amblyopsis spelæus DeKay. } \\
& \text { Typhlichthys subterraneus Girard. }
\end{aligned}
$$

Acanthocheir armata Tellk. Phrixis longipes Cope. Anthrobia monmouthia Tellk.

Anthrobia.

Orconectes inermis Cope. Cæcidotea microcephala Cope. Cauloxenus stygius Cope.

Anophthalmus tenuis Horn. Anophthalmus eremita Horn. Quedius spelæus Horn. Lesteva sp. nov. Horn. Raphidophora.

Phora.

Anthomyia.

Machilis,

Campodea sp.

Tipulid Crustacea

Orconectes pellucidus Tellk.

Cacidotea stygia Pack.

Stygobromus vitreus Cope.

Insecta.

Anophthalmus Menetriesii Motsch. Anophthalmus Tellkampfii Erichs. Adelops hirtus Tellk.

Raphidephora subterranea Scudd.

Phora.

Anthomyia.

Machilis.

Campodea Cookei Pack.

Pirostrephon cavernarum Cope.

Myriopoda.

The blind fish of the Wyandctte Cave is the same as that of the Mammoth, the Amblyopsis spelaus DeKay. It must have considerable subterranean distribution, as it has undoubtedly been drawn up from four wells in the neighbourhood of the cave. Indeed, it was from one of these, which derives its water from the cave, that we procurcd our specimens. We descended a well to the water, some twenty feet below the surface, and found it to communicate by a side opening with a long low channel, through which flowed a lively stream of very cold water. Wading up the current in a stooping posture, we soon reached a shallow expansion or pool. Here a blind crawfish was detected crawling round the margin, and was promptly consigned to the alcohol bottle. A little farther beyond, deeper water was reached, and an erect position became possible. We drew the seine in a narrow channel, and after an exploration under the bordering rocks, secured two fishes. A second haul secured another. Another was seen, but we failed to catch it, and on emerging from the cave I had a fifth securely in my hand, as I thought, but found my fingers too numb to prevent its freeing itself by its active struggles.

If these Amblyopses be not alarmed, they come to the surface to feed, and swim in full sight like white aquatic ghosts. They are then easily taken by the hand or net, if perfect silence is preserved, for they are unconscious of the presence of an enemy except through the medium of hearing. This sense is, however, evidently very acute, for at any noise they turn suddenly downward and hide beneath stones, \&c., on the bottom. They must take much of their food near the surface, as the life of the depths is apparently very sparse. This habit is rendered easy by the structure of the fish, for the mouth is directed partly upwards, and the head is very flat above, thus allowing the mouth to be at the surface. It thus takes food with less difficulty than other surface feeders, as the perch, \&c., where the mouth is terminal or even inferior; for these require a definite effort to elevate the mouth to the object floating on the surface. This could rarely be done with accuracy by a fish with defective or atrophied visual organs. It is therefore probable that fishes of the type of the Cyprinodontida, the nearest allies of the Hypsaida, and such $F$ yypseida as the eyed Chologaster, would possess in the position of the mouth a slight advantage in the struggle for existence.

The blind crawfish above mentioned is specifically distinct from that of the Mammoth Cave, though nearly related to it. I call it Orconectes incrmis, separating it gencrically from Cambarus, or the true crawfishes, on account of the absence of visual organs. The genus Orconectes, then, is established to include the blind crawfishes of the Mammoth and Wyandotte Caves.

Dr. Packard has described an interesting genus of Isopoda allied to the marine form Idotaa, which Mr. Cooke discovered in a pool in the Mammoth Cave. He called it Cacidotea. I obtained a second species in a cave adjoining the Wyandotte which differs in several important respects. I call it Cacidotea microcephala. Both species are blind. The new species is pure white. It was quite active, and the females carried a pair of egg-pouches full of eggs. The situation in which we found it was peculiar. It was only seen in and near an empty $\log$ trough used to collect water from a spring dripping from the roof of one of the chambers.

The Lernæan, Cauloxenus stygius Cope, is a remarkable creature. It is a parasite on the blind fish, precisely as numerous species near of kin attach themselves to various species of marine fishes. The Wyandotte species is not so very unlike some of these. It is attached by a pair of altered fore-limbs, which are plunged into the skin of the host, and held securely in that position by the barbed or recurved claws. No parasitic male was observed in the neighbourhood of the female, and it is probable that, as in the other Lcrnceopudida, he is a free swimmer, and extremely small. The difficulty of finding his mate on an active host-fish must be augmented by the total darkness of his abode, and many must be isolated owing to the infrequent and irregular occurrence of the fish, to say nothing of the scarceness of its own species.

The allied genera, Achtheres and Lernceopoda, present very distinct distributions, the former being fresh water and the latter marine. Lerncopoda is found in the most varied tvpes of fishes and in several seas; Achtheres has becn observed on perch from Asia and Europe, and on a South American Fimclodus. It is to the latter that Cauloxemus is most nearly allied, and from such a form we may, perbaps, trace its descent ; modification being consequent on its wandering into subterranean streams. The character which distinguishes it from its allies is one which especially adapts it for maintaining a firm hold on its bost, i.c., the fusion of its jaw-arms into a single stem.

Whether the present species shared with the Amblyopsis its history and changes, or whether it seized upon the fish as a host at some subsequent period, is a curious speculation. Its location at the mouth of the fish could scarcely be maintained on a species having sight ; for if the host did not remove it, other individuals would be apt to.

I may here allude to another blind Crustacean which I took in the Mammoth Cave, and which has been already mentioned in the Annals and Magazine of Natural History as a Gammaroid. Mr. Cooke and myself descended a hole, and found, a short distance along a gallery, a clear spring, covering, perhaps, an area ten feet across. Here $\mathrm{Mr}$. Cooke was so fortunate as to procure the Cacidotea stygia, while I took the species just mentioned, and which I name Stygobromus vitreus. The genus is new, and represents in a measure the Niphargus of Schiödte found in the caves of Southern Europe. This genus has several species in fresh waters, which are of small size, and swim actively, turning on one side or the other.

Of Insects I took four species of beetles, all new to science; two of them of the blind carnivorous genus Anopthihalmus, and two Staphylinude, known by their very short wing-cases and long, flexible abdomen. Dr. George $\mathrm{H}$. Horn has kindly determined them. for me. 
One of them, the Quedius spelaus, Horn, is half an inch in length, and has rather small eyes; it was found not far from the mouth of the cave. Dr. Horn furnishes me with the following list of Coleoptera from the two caves in question :-

Anophthalmus Tellkampfii Erichs.

$$
\begin{aligned}
& \text { Menetriesi Motsch, angz- } \\
& \text { latus Lec. }
\end{aligned}
$$$$
\text { eremita Lec. }
$$

tenuis Horn.

striatus Motsch.

ventricosus Motsch.

Mammoth Cave.

Mammoth Cave.

Wyandotte Cave.

Wyandotte Cave

Mammoth Cave. Unknown to me. Mammoth Cave. Unknown to me. Mammoth Cave.

Adelops hirta Tellk.

These are the only true cave insects at present known in these faunæ. Other species were collected within the mouths of the caves, but which cannot be classed with the preceding, as cave insects proper.

$$
\begin{array}{ll}
\text { Catops n. sp. ? } & \text { Wyandotte Cave. } \\
\text { Quedius spelæus Horn. } & \text { Wyandotte Cave. } \\
\text { Lestev n. spa, } & \text { Wyandotte Cave. }
\end{array}
$$

And another Alæocharyde Staphylinide, allied to Tachyusa, also from Wyandotte Cave. No names have as yet been given to any of these, excepting the second. A monograph of Catops has already appeared containing many species from our fauna ; and as the work is inaccessible at present, I have hesitated to do more than indicate the presence of the above species.

The cricket of the Wyandotte Cave is stouter than that of the Mammoth, and thus more like the Raphidophora lapidicola of the forest. There were three species of flies, one or more species of Podurida, and a Campodea not determined.

Centipedes are much more abundant in the Wyandotte than in the Mammoth Cave. They especialiy abounded on the high stalagmites which crown the hill beneath the Mammoth dome, which is three miles from the mouth of the cave. The species is quite distinct from that of the Mammoth Cave, and is the one I described some years ago from caves in Virginia and Tennessee. I call it Spirostrephon cavernarum, agreeing with Dr. Packard that the genus Pseudotremia, to which it was originally referred, is of doubtful validity. The allied form found by Mr. Cooke in the Mammoth Cave has been described by Dr. Packard as Spirostrephon Copei. It is eyeless, and is, on this account alone, worthy of being distirguished generically from spirostrephon. This genus may be then named Scoterpes. I look for the discovery of $S$. caver. narum in the Mammoth Cave.

Two species of Arachnidans were observed, one a true spider, the other related to the "long-legs" of the woods. A species similar to the former is found in the Mammoth Cave, and others in other caves, but in every instance where I have obtained them they have been lost by the dissolution of their delicate tissues in the impure alcohol. The other forms are more completely chitinised, and are easily preserved ; they are related to the genus Gonyleptes, found under stones in various portions of the country. Dr. Wood describes a species from Texas, and I have taken them in Tennessee and Kansas. In the Wyandotte Cave I found a number of individuals of a new species, at a place called the screw-hole. Though living at a distance of four or five miles from the mouth of the cave, this species is furnished with eyes. This species is described as Erebomaster flavescens Cope. In its relationships it may be said to stand between Acanihoiheir and Gonyleptes.

Besides Acanthocheir, another blind Gonyleptid exists in the Mammoth Cave, which I found several miles from the mouth. It is blind like the former, but differs in having many more joints to the tarsi, approaching thus the true Phalangia, or long-legs.

Dr. Packard and Mr. Putnam have already discussed the question of the probability of the origin of these blind cave animals by descent from out-door species having eyes. I have already expressed myself in favour of such view, and deem that in order to prove it we need only establish two or three propositions. Firet, that there are eyed genera corresponding closely in other general characters with the blind ones; second, tha: the condition of the visual organs is in some cave type variable; third, if the abortion of the visual organs can be shown to take place coincidently with general growth to maturity, an important point is gained in explanation of the modrts operandi of the process.

First, as to corresponding forms; the Typhlichthys of the Mammoth is identical with Chologaster, except in its lack of eyes. Orconectes bears the same relation to $C a m$. barus ; Stygobromus bears nearly the same to Gammarus; and Scoterpes is Spirostrephon without eyes and no pores.

Secondly, as to variability. I have already shown that in Gronias nigrilabris, the blind Silurid from the Conestoga in Pennsylvania, while all of several specimens observed were blind, the degree of atrophy of the visual organs varies materially, not only in different fishes, but on different sides of the same fish. In some the corium is imperforate, in others perforate on one side, in others on both sides, a rudimental cornea being thus present. In some the ball of the eye is oval, and in others collapsed. This fish is related specifically to the Amiurus nebulosits of the same waters, more nearly than the latter is to certain other Amiuri of the Susquehanna river basin to which the Conestoga belongs, as for instance the A. Lynx; it may be supposed to have been enclosed in a subterranean lake for a shorter time than the blind fishes of the Western Caves, not only on account of the less degree of loss of visual organs, but also in view of its very dark colours.

Thirdly, it is asserted that the young Orconectes possess eyes, and that perhaps those of the Typhlichthys do also. If these statements be accurate, we have here an example of what is known to occur elsewhere, for instance, in the whalebone whales. In a fotal stage these animals possess rudimentary teeth like other Cetacea, which are subsequently absorbed. This disappearance of the eyes is regarded with reason by Prof. Wyman as evidence of the descent of the blind forms from those with visual organs. I would suggest that the process of reduction illustrates the law of "retardation," accompanied by another phenomenon. Where characters which appear latest in embryonic history are lost, we have simple retardationthat is, the animal in successive generations fails to grow up to the highest point, falling farther and farther back, thus presenting an increasingly slower growth in this special respect. Where, as in the presence of eyes, we have a character early assumed in embryonic life, the retardation presents a somewhat different phase. Each successive generation, it is true, fails to come up to the completeness of its predecessor at maturity, and thus exhibits "retardation;" but this process of reduction of rate of growth is followed by its termination in the part long before growth has ceased in other organs. This is an exaggeration of retardation. Thus the eyes in the Orconectes probably once exhibited at maturity the incomplete characters now found in the young, for a long time a retarded growth continuing to adult age before its termination was gradually withdrawn to earlier stages. Growth ceasing entirely, the phase of atrophy succeeded, the organ became stationary at an early period of general growth, being removed, and its contents transferred to the use of other parts by the activity of "growth force." Thus, for the loss of late assumed organs we have "retardation," but for that of early assumed ones, "retardation and atrophy."

The mutual relations of this cave life form an interesting subject. In the first place, two of the beetles, the crickets, the centipede, the small crustaceans (food of the blind fish) are more or less herbivorsus. They furnish food for the spiders, crawfish, Anophthalmus, and the fish. The vegetable food supporting them is in the first place fungi which, in various small forms, grow in damp 
places in the cave, and they can always be found attached to excrementitious matter dropped by the bats, rats, and other animals which extend their range to the outer air. Fungi also grow on the dead bodies of the animals which die in the caves, and are found abundantly on fragments of wood and boards brought in by human agency. The rats also have brought into fissures and cavities communicating with the cave, seeds, nuts, and other vegetable matters, from time immemorial, which have furnished food for insects. Thus rats and bats have, no doubt, had much to do with the continuance of land life in the cave, and the mammals of the post-pliocene or earlier period, which first wandered and dwelt in its shades, were introducers of a permanent land life.

As to the small crustaceans, little food is necessary to support their small economy, but even that little might be thought to be wanting, as we observe the clearness and limpidity of the water in which they dwell. Nevertheless the fact that some cave waters communicate with outside streams is a sufficient indication of the presence of vegetable life and vegetable débris in variable quantities at different times. Minute fresh water algæ no doubt occur there, the spores being brought in by external communication, while remains of larger forms, as confervæ, \&c., would occur plentifully after floods. In the Wyandotte Cave no such connection is known to exist. Access by water is against the current of small streams which discharge from it. On this basis rests an animal life which is limited in extent, and must be subject to many vicissitudes. Yet a fuller examination will probably add to the number of species, and of these, no doubt, a greater or less number of parasites on those already known. The discovery of the little Lernæan shows that this strange form of life has resisted all the vicissitudes to which its host has been subjected. That it has outlived all the physiological struggles which a change of light and temperature must have produced, and that it still preys on the food of its host, as its ancestors did, there is no doubt. The blindness of the fish has favoured it in the "struggle for existence," and enabled it to maintain a position nearer the commissariat, with less danger to itself than did its forefathers.

E. D. Copr.

\section{SCOTTISH COAL FIELDS}

"THE "Journal of the Iron and Steel Institute" for August contains Prof. Geikie's paper read at the recent meeting in Glasgow "On the Geological Position and Features of the Coal and Ironstone-bearing Strata of the West of Scotland." The paper is meant chiefly for the benefit of those who are acquainted only with the British Carboniferous strata as seen in the English coal-fields, and to point out the geological position of the Scottish carboniferous deposits as contrasted with those of England. A geological map of Scotland shows that the Carboniferous formation is for the most part restricted to that broad belt of undulating low ground that extends from sea to sea, between the northern highlands on the one hand, and the southern uplands on the other. Throughout this area the strata are arranged in a series of great basins with intervening ridges. The chief basins, beginning in the east, the basins of Fifeshire, and Midlothian being first; second, the Lanarkshire and Stirlingshire basin; third, the broken and interrupted basins of Ayrshire and the south. This system is capable of being divided into four great series, which, beginning at the top, are as follows:-(r) the Coal Measures, (2) the Millstone Grit, (3) the Carboniferous Limestone (4) the Calciferous Sandstone series.

From Prof. Geikie's review of the more characteristic features assumed by the Scottish Carboniferous system, it is evident that the series which diverge most from those that are typical of the English area are the Calciferous Sandstones and the overlying Carboniferous Limestone series. In England, the strata that underlie the Coal Measures and Millstone Grit are composed almost exclusively of beds which have been amassed upon a sea bottom. In Scotland, on the other hand, we find the strata upon which the true Coal Measures and Millstone Grit repose giving evidence of numerous interchanges of land, fresh or brackish water, and marine conditions; while at the same time we are assured that during the accumulation of these underlying strata the eruption of melted matter hardly ever ceased in central Scotland.

\section{NOTES}

THOSE interested in the early history of geolozy will be glad to learn that a work is announced as ready for publication, with the title, "A Book about William Smith and the Somersetshire Coal Canal; being an Account of the Commencement of Stratigraphical Geology in England." The book is illustrated by a series of consecutive photographs of the districts along the north side of the Canal valley, and each photograph is accompanied by a geologically coloured key, which shows at a glance the outcrop of the various strata. This method is, as far as we know, quite original, and serves to show clearly the data with which Snith dealt in arriving at his discoveries.

THE Vice-Chancellor of the University of Cambridge, in resigning his office, referred to the progress made by the University in encouraging new branches of study. He commented upon the extension of the infuence of the University over the studies in the kingdom, and the increasing desire on the part of thuse engaged in the work of education to be brought more closely in contact with the University. The yearly increase in the number of candidates for the Middle-class Examinations, and the institution of an examination for the higher grade schools, evidenced the fact of the extending influence of the University. The ViceChancellor referred to the munificence of the Chancellor, the Duke of Devonshire, in providing a school for Experimental Physics, and congratulated the University upon the approaching completion of the building of the Fitzwilliam Museum. The acquisition of the Leckenby collection of fossils to the Woodwardian Museum was a worthy proof of the liberality of the Colleges and members of the University, as well as a graceful acknowledgement of the services of Prof. Sedgwick. The donations of Lord Walsingham and Miss Walcott were likewise valuable additions to the collections in the above-mentioned museum. Among other bequests and donations, the Vice-Chancellor particularly alluded to the bequests of Sir John Herschel and the Rev. R. E. Kerrich, and especially to the generosity of the Earl of Portsmotth in presenting the MSS. of Sir Isaac Newton.

There has been a marked increase during the present term in the University of Cambridge in the number of students who take advantage of the privilege of being allowed to reside out of their college. Since the scheme was established in 1869 , eighty students have been admitted, a considerable number of whom devote themselves to the stud/ of natural science. The University payments for nine terms' residence, including the B.A. degree, do not greatly exceed $30 l$., and even with books and a 7 . ditional instruction the amount need not be much over $50 l$. Th : number of freshmen entered at the University this year is 622 , as compared with 572 last year.

DR. BRoWn-SEQUARD, the eminent physiologist, has resigned the chair of Comparative and Experimental Pathology in the Faculty of Medicine in Paris, which he has occupied for several years. It is understood that this is preliminary to establishing his permanent residence in Boston, U.S.A.

AT a meeting of the Council of the Royal College of 